\title{
Total body electrolyte composition in patients with heart failure: a comparison with normal subjects and patients with untreated hypertension
}

\author{
JOHN G F CLELAND,* HENRY J DARGIE,* IAN ROBERTSON, $\dagger$ \\ J IAN S ROBERTSON, $\ddagger$ B W EAST $\dagger$
}

From the ${ }^{\star}$ Department of Cardiology, Western Infirmary, Glasgow; $\uparrow$ Scottish Universities Research Reactor Centre, East Kilbride; and $\ddagger$ Medical Research Council Blood Pressure Unit, Western Infirmary, Glasgow

SUMMARY Total body elemental composition was measured in 40 patients with well documented heart failure who were oedema-free on digoxin and diuretics. The results were compared with values for 20 patients with untreated essential hypertension matched for height, weight, age, and sex. Total body potassium alone was also measured in 20 normal subjects also matched for anthropomorphic measurements. Patients with hypertension had a very similar total body potassium content to that of normal subjects, but patients with heart failure had significantly reduced total body potassium. This could not be explained by muscle wasting because total body nitrogen, largely present in muscle tissue, was well maintained. When total body potassium was expressed as a ratio of potassium to nitrogen mass a consistent depletion of potassium was revealed in the group with heart failure. Potassium depletion was poorly related to diuretic dose, severity of heart failure, age, or renal function. Activation of the renin-angiotensin-aldosterone system was, however, related to hypokalaemia and potassium depletion. Such patients also had significantly lower concentrations of serum sodium and blood pressure. Serum potassium was related directly to total body potassium. Despite the absence of clinically apparent oedema total body chlorine was not consistently increased in heart failure, but the calculated extracellular fluid volume remained expanded in the heart failure group. Total body sodium was significantly increased in patients with heart failure, but less than half of this increase could be accounted for by extracellular fluid volume expansion.

Potassium depletion in heart failure may account in part for the high frequency of arrhythmias and sudden death in this condition.

After many years of debate there is still controversy about the prevalence, extent, and relevance of potassium depletion in patients treated with diuretics for heart failure. ${ }^{1-6}$ Reports of reduced body potassium in such patients have been attributed to lack of good control data or to muscle wasting in "cardiac cachexia."1 Some of the difficulty may have arisen because of the absence of a definitive diagnosis of heart failure, which has largely been resolved by new

Requests for reprints to Dr John G F Cleland, Waller Department of Cardiology, St Mary's Hospital, Praed Street, London W2 1 NY.

Accepted for publication 31 March 1987 diagnostic techniques, in particular echocardiography. Also, the measurement of total exchangeable potassium requires a prolonged equilibration time after the administration of radioactive tracers and this can introduce inaccuracies. ${ }^{57}$ Measurement of total body potassium by the endogenous ${ }^{40} \mathrm{~K}$ isotope avoids this difficulty. It is also difficult to define adequate control groups for comparison. Body elemental composition is highly dependent on body mass, adiposity, age, and sex. ${ }^{8}$ Control groups have rarely been adequately matched with patients in heart failure, nor have appropriate corrections usually been made.

Patients with severe heart failure have a poor prognosis, the one year survival for a patient with 
New York Heart Association grade III heart failure being approximately $60 \% .{ }^{9}{ }^{10}$ Interest in potassium depletion in heart failure was renewed by the observation that potassium depletion can be corrected, arrhythmias reduced, and possibly prognosis improved by angiotensin converting enzyme inhibitors. ${ }^{1112}$

The technique of in vivo total body neutron activation analysis performed on the same day for all elements also has allowed us to measure total body sodium, chlorine, phosphorus, calcium, and nitrogen. Nitrogen is an index of protein mass ${ }^{13}$-muscle, collagen, and the viscera being the major sites of this element. ${ }^{14}$ Measurement of body nitrogen allows us to correct for leanness. In vivo neutron activation analysis requires a dose of radiation that cannot be justified in normal subjects. We used endogenous ${ }^{40} \mathrm{~K}$ measurements followed by activation analysis to assess body composition in untreated patients with essential hypertension, ${ }^{15}$ which does not differ from normal values. We have also measured total body potassium in a large series of normal subjects and found no difference from the mean value in patients with untreated essential hypertension who were matched for age and sex. ${ }^{1617}$ We have therefore compared patients treated for heart failure with diuretics and digoxin with patients with untreated essential hypertension and with normal subjects matched for height, weight, age, and sex.

\section{Patients and methods}

\section{PATIENTS}

Forty patients referred to the cardiac department for further investigation and treatment of heart failure were compared with 20 subjects without evidence of cardiac or other disease and 20 patients with untreated essential hypertension. Heart failure was confirmed by the measurement of a raised left ventricular end diastolic pressure $(>16 \mathrm{~mm} \mathrm{Hg})$ and poor stroke volume on left ventricular cineangiography, with a fractional shortening on $\mathbf{M}$ mode echocardiography of less than $20 \%$ (14 (3)\%, mean (SEM)) and end diastolic dimension greater than $6 \mathrm{~cm}(6.4(0.2) \mathrm{cm})$. The aetiology of cardiac failure was ischaemic heart disease in 20, idiopathic (dilated cardiomyopathy in 17, and severe residual left ventricular dysfunction after successful valve replacement in three (two aortic, one mitral and aortic). Nine were in early heart failure (New York Heart Association class IV) but did not suffer undue orthopnoea, 18 in class III, and 13 in class II. All patients had received at least $80 \mathrm{mg} /$ day of frusemide (mean 147 (13) $\mathrm{mg} /$ day) for more than three months (mean (SEM) duration 11 (5) months). In addition to frusemide, five were taking bendrofluazide $5-10 \mathrm{mg} /$ day. Twelve were taking potassium chloride in a mean daily dose of $2 \cdot 1(0 \cdot 1) \mathrm{g}$, but none was taking potassium-sparing diuretics.

Table 1 shows the mean blood pressure in the groups with hypertension and heart failure. All those with hypertension were symptom free without clinical, biochemical, or radiological features of heart failure, aortic coarctation, Cushing's syndrome, primary hyperaldosteronism, renal disease, or phaeochromocytoma. Any previous treatment had been withdrawn at least four weeks before the measurements were made.

\section{METHODS}

We measured nude weight and height in each subject. Blood pressure was recorded in supine patients by a standard sphygomomanometer with phase $\mathrm{V}$ as the diastolic pressure. Total body potassium was measured by whole body counting of endogenous ${ }^{40} \mathrm{~K}$ before irradiation. ${ }^{18}$

Total body sodium, chlorine, calcium, phos-

'able 1 Comparison of total body potassium in normal subjects and in patients with hypertension and heart failure

\begin{tabular}{|c|c|c|c|c|c|c|c|c|c|}
\hline & \multicolumn{3}{|c|}{$\begin{array}{l}\text { Normal }(16 M / 20 F) \\
\text { Mean }\end{array}$} & \multicolumn{3}{|c|}{$\begin{array}{l}\text { Hypertension }(15 M / 20 F) \\
S E M\end{array}$} & \multicolumn{3}{|c|}{$\begin{array}{l}\text { Heart failure }(32 M / 40 F) \\
\text { Range }\end{array}$} \\
\hline & Normal & Hypertension & $\begin{array}{l}\text { Heart } \\
\text { failure }\end{array}$ & Normal & Hypertension & $\begin{array}{l}\text { Heart } \\
\text { failure }\end{array}$ & Normal & Hypertension & $\begin{array}{l}\text { Heart } \\
\text { failure }\end{array}$ \\
\hline $\begin{array}{l}\text { ge (years) } \\
\text { eight }(\mathrm{cm}) \\
\text { leight (kg) } \\
\text { 'otal body }\end{array}$ & $\begin{array}{r}52 \\
170 \\
69\end{array}$ & $\begin{array}{r}53 \\
168 \\
69\end{array}$ & $\begin{array}{r}56 \\
167 \\
68\end{array}$ & $\begin{array}{l}3 \\
2 \\
2\end{array}$ & $\begin{array}{l}3 \\
2 \\
3\end{array}$ & $\begin{array}{l}1 \\
1 \\
2\end{array}$ & $\begin{array}{c}31-72 \\
154-184 \\
47-92\end{array}$ & $\begin{array}{c}30-71 \\
151-186 \\
44-109\end{array}$ & $\begin{array}{c}28-64 \\
146-180 \\
45-88\end{array}$ \\
\hline $\begin{array}{l}\text { potassium (mmol) } \\
\text { otal body }\end{array}$ & 3208 & 3250 & $2831^{\star} \dagger$ & 131 & 171 & 93 & $2315-4274$ & $2043-4951$ & $1518-4031$ \\
\hline $\begin{array}{l}\text { nitrogen (g) } \\
\text { otal body }\end{array}$ & 1642 & 1640 & 1688 & 51 & 59 & 49 & 1239-2093 & $1128-2109$ & $1090-2285$ \\
\hline $\begin{array}{l}\text { potassium: nitrogen } \\
\text { ratio (mmol:g) }\end{array}$ & 1.95 & 1.97 & $1 \cdot 68 \pm \S$ & 0.04 & 0.05 & 0.03 & $1 \cdot 67-2 \cdot 35$ & $1 \cdot 54-2 \cdot 35$ & $1 \cdot 34-2 \cdot 09$ \\
\hline
\end{tabular}

p 0.02 vs normal; tp 0.05 vs hypertension; †p 0.0001 vs normal; \$p 0.0001 vs hypertension. 
phorus, nitrogen, and oxygen were measured simultaneously by activation with $14 \mathrm{MeV}$ neutrons followed by whole body counting ${ }^{19-25}$ in the two patient groups only. The radiation dose was not justified in normal subjects. In normal subjects total body nitrogen was predicted from anthropomorphic measurements. During total body in vivo neutron activation analysis (TBIVAA) the patient lay on a bed which was driven between two neutron generators and received a radiation dose equivalent of $1 \mathrm{rem}(10 \mathrm{mSv})$ at the body surface. Induced radioactivity was then measured in a high sensitivity shadow shielded whole body counter by two sodium iodide detectors with repeated counting scans for up to 30 minutes after irradiation. The calibration and reproducibility of these measurements are described elsewhere, but replicate measurements are generally within 3\%. ${ }^{192122}$ Values are expressed in $\mathrm{mmol}$ for sodium, potassium, and chlorine; in grams for calcium, phosphorus, and nitrogen, and in kilograms for oxygen. Values were also expressed as a percentage of the predicted normal. The normal values for total body potassium are predicted from those obtained by Boddy et $\mathrm{al}^{,{ }^{18}}$ in a large series of normal subjects at our own facility, and based on height, weight, age, and sex. To predict total body sodium and calcium we used equations derived from neu- tron activation analysis measurements in normal subjects made by Ellis et $a^{2425}$ that relate total body in vivo neutron activation analysis measurements to height, weight, age, and sex. Equations for the prediction of total body chlorine values were based on measurements of extracellular fluid volume made with radioactive bromine. ${ }^{26}$ Extracellular fluid volume was calculated from total body chlorine and serum chloride. ${ }^{27}$ "Dry" weight also was estimated for the heart failure group by correcting their weight to the same extracellular fluid volume per $\mathrm{kg}$ as the hypertensive group. Predicted values for total body nitrogen were derived from the formula $\mathrm{N}(\mathrm{g})=322$ $x$ height $^{3}+81$ in hypertensive subjects; this is regarded as an accurate method of prediction. ${ }^{15}$ Potassium was also expressed as $\mathrm{mmol} / \mathrm{g}$ of nitrogen as suggested by Burkinshaw and Morgan. ${ }^{28}$

Since phosphorus was not measured in normal subjects, and as the amounts of calcium and phosphorus are normally closely related, the ratio $(\mathrm{P} / \mathrm{Ca})$ was used. ${ }^{15}$ Total body oxygen in normal subjects has not been measured by this technique.

Blood was drawn at 9 am from fasting patients who had been supine overnight and again at $4 \mathrm{pm}$ in patients who had been supine for 30 minutes. Sodium, potassium, chloride, urea, creatinine, and phosphate were measured and the results were

Table 2 Comparison of measurements in patients with hypertension and heart failure

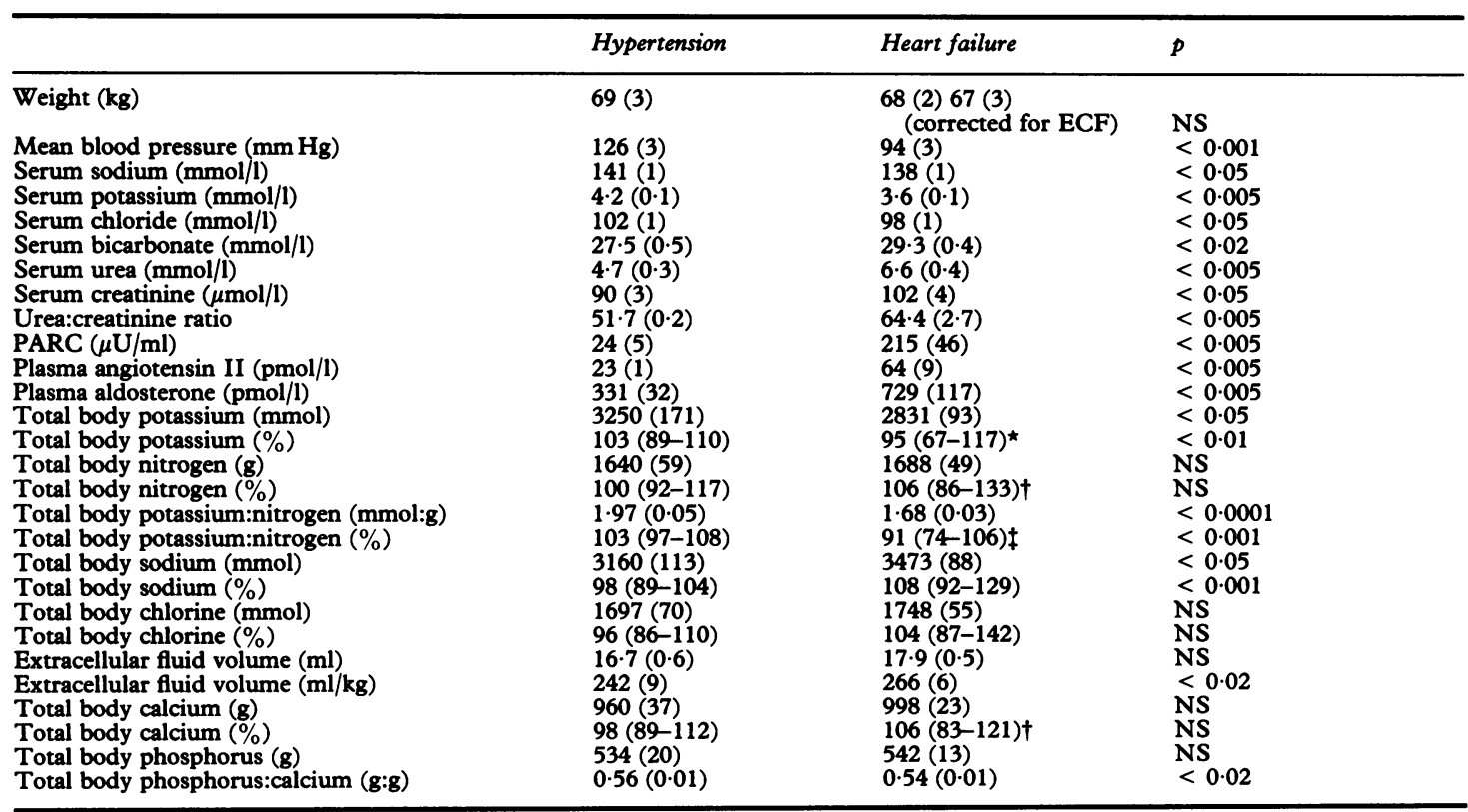

ECF, extracellular fluid volume; \%, percentage of normal predicted; PARC, plasma active renin concentration.

${ }^{\star} \mathrm{p}<0.05,+\mathrm{p}<0.001, \ddagger \mathrm{p}<0.001$ compared with predicted normal (see text).

Values are mean (SEM) for absolute values and mean and range for percentage values. 
expressed as the mean of the two values. Plasma concentrations of active renin, angiotensin II, and aldosterone were measured in the 9 am sample. ${ }^{29-32}$

\section{STATISTICAL ANALYSIS}

For group analysis we used Student's $t$ test or the Wilcoxon rank sum test for non-parametrically distributed variables. Results for patients with heart failure and hypertension were expressed as the ratio of calculated to predicted normal, $100 \%$ representing no difference between calculated and predicted values. A single parameter $t$ test was used to test for systematic deviation from predicted values. We used a $5 \%$ level of significance. Correlations were performed by the method of least squares for variables with bivariate normal distribution and by Spearman's rank correlation for non-parametrically distributed data.

\section{Results}

ANTHROPOMORPHIC MEASUREMENTS (TABLE 1) The normal subjects and patients with hypertension and heart failure were similar with respect to height, weight, age, and sex. Subgroups of heart failure patients with normal and raised renin were similar, and neither group differed from the normal or hypertensive group. The similarity in weight persisted even when the weight of the heart failure groups was corrected for the higher extracellular fluid volume (table 2).

\section{BLOOD PRESSURE (TABLE 2)}

Though the blood pressure in the hypertensive group was not greatly raised (170 (3)/105 (3) $\mathrm{mm} \mathrm{Hg}$ ) mean blood pressure was significantly greater than in those with heart failure (132 (2)/78(1)).

\section{SERUM ELECTROLYTES (TABLE 2)}

Serum sodium, potassium, and chloride were significantly higher in those patients with hypertension, while serum bicarbonate, urea, and creatinine were higher in those with heart failure.

\section{HORMONES (TABLE 2)}

Plasma concentrations of active renin, angiotensin II, and aldosterone were considerably higher in subjects with heart failure. Only two subjects with hypertension had plasma active renin concentration outside the normal range compared with 26 patients with heart failure.

TOTAL BODY COMPOSITION (TABLES 1-3)

Total body potassium was lower in patients with heart failure than in normal controls, the hypertensive group, and the predicted normal values.
Total body potassium was normal in the hypertensive group as previously reported. Mean total body sodium was normal in the hypertensive group but raised in the group with heart failure compared with the hypertensive group or with predicted normal values. Total body chlorine was not significantly different in the two groups and did not deviate significantly from the predicted value. Although total extracellular fluid volume was similar in hypertensive patients and patients with heart failure, when results were corrected for body weight, patients with heart failure had a significantly expanded volume despite being free from clinically apparent oedema. Total body calcium was higher in patients with heart failure but the value for phosphorus was similar in both groups of patients. The ratio of phosphorus to calcium was consequently lower in the patients with heart failure.

Absolute values for total body nitrogen were similar in the heart failure group, normal controls, and hypertensive patients. When expressed as a percentage of predicted normal, nitrogen values were increased only in the heart failure group. The difference in potassium expressed in $\mathrm{mmol} / \mathrm{g}$ of nitrogen was thus highly significant; values were much lower in those with heart failure. After correction for nitrogen values subjects with heart failure were approximately $12 \%$ depleted of potassium compared with hypertensive patients.

\section{COMPARISON OF SUBGROUPS OF CARDIAC FAILURE PATIENTS WITH LOW OR NORMAL RENIN CONCENTRATIONS AND THOSE WITH RAISED CONCENTRATIONS (TABLE 4)}

We used a cut off point of $50 \mu \mathrm{U} / \mathrm{ml}$ for plasma active renin concentration; this was the upper limit of normal for our laboratory. Subjects in each group were well matched for anthropomorphic measurements, though the high renin group had an excess of men. The patients with high plasma renin $(n=26)$ had correspondingly high plasma concentrations of angiotensin II and aldosterone. There was no difference in the severity of heart failure or diuretic requirements between the groups. Total body and serum potassium, serum sodium, and mean blood pressure were all inversely related to plasma renin (figs 1-4). Potassium supplements were significantly greater in those subjects with low serum potassium and raised plasma renin. Extracellular fluid volume was not contracted in those with a high plasma renin. Only two hypertensive patients had raised plasma renin.

CORRELATIONS BETWEEN SERUM AND TOTAL BODY ELECTROLYTES

Serum and total body potassium (expressed as a per- 
Table 3 Total body oxygen in patients with hypertension and patients with heart failure

\begin{tabular}{llll}
\hline & Hypertension & Heart failure \\
\hline No & 7 & 32 \\
Total body oxygen $(\mathrm{kg})$ & $42.9(3.0)$ & $36.0(2.3)$ \\
Total body oxygen (\%) & $104(89-112)$ & $93(76-109)$ & $<0.05$ \\
Total body oxygen (kg/kg body weight) & $0.59(0.05)$ & $0.54(0.07)$ & $<01$ \\
TBK/TBO (mmol/kg) & $80(5)$ & $79(9)$ & 0.01 \\
TBNa/TBO (mmol/kg) & $79(8)$ & $95(9)$ & $<0.001$
\end{tabular}

TBO, total body oxygen; TBK, total body potassium; TBNa, total body sodium; \%, percentage of predicted normal. Values are mean (SEM) for absolute values and mean (range) for percentage values.

Table 4 Comparison of measurements in patients with heart failure and with normal or high renin concentrations

\begin{tabular}{|c|c|c|c|}
\hline & $\operatorname{Renin}<50 \mu U / m l$ & $\operatorname{Renin}>50 \mu U / \mathrm{ml}$ & $p$ \\
\hline $\begin{array}{l}\text { Proportion of men to total } \\
\text { Age (years) } \\
\text { Height (cm) } \\
\text { Weight (kg) } \\
\text { NYHA } \\
\text { Frusemide (mg/day) } \\
\text { Bendrofluazide } \\
\text { Potassium chloride (mg/day) } \\
\text { Mean blood pressure (mm Hg) } \\
\text { Serum sodium (mmol/l) } \\
\text { Serum potassium (mmol/l) } \\
\text { Serum chloride (mmol/l) } \\
\text { Serum bicarbonate (mmol/l) } \\
\text { Serum urea (mmol/l) } \\
\text { Serum creatinine ( } \mu \text { mol/l) } \\
\text { Urea:creatinine ratio } \\
\text { PARC ( } \mu \text { U/ml) } \\
\text { Plasma angiotensin II (pmol/l) } \\
\text { Plasma aldosterone (pmol/l) } \\
\text { Total body potassium (\%) } \\
\text { Total body nitrogen (\%) } \\
\text { Total body potassium:nitrogen (mmol:g) } \\
\text { Total body potassium:nitrogen (\%) } \\
\text { Total body sodium (\%) } \\
\text { Total body chlorine (\%) } \\
\text { Extracellular fluid volume (ml/kg) } \\
\text { Total body calcium (\%) } \\
\text { Total body phosphorus:calcium } \\
\text { Total body oxygen (kg/kg body weight) }\end{array}$ & $\begin{array}{l}9 / 14 \\
58(1) \\
163(3) \\
67(3) \\
3(2-4) \\
124(16) \\
2 \text { patients } \\
343(0-1200) \\
109(4) \\
141(1) \\
4 \cdot 0(0 \cdot 1) \\
100(1) \\
29(1) \\
6 \cdot 2(0 \cdot 4) \\
101(7) \\
60(2) \\
33(4) \\
20(3) \\
272(31) \\
105(95-117)^{\star} \\
109(90-133) \star \\
1 \cdot 78(0 \cdot 05) \\
97(94-106) \\
110(96-129)^{\star} \\
107(88-142) \\
260(9) \\
106(86-118) \\
0 \cdot 54(0 \cdot 01) \\
0 \cdot 53(0 \cdot 05)\end{array}$ & $\begin{array}{l}23 / 26 \\
55(2) \\
168(1) \\
68(2) \\
3(2-4) \\
158(18) \\
3 \text { patients } \\
1080(0-2040) \\
87(2) \\
137(1) \\
3.5(0 \cdot 1) \\
97(2) \\
29(1) \\
6.8(0 \cdot 6) \\
103(5) \\
70(2) \\
313(62) \\
87(12) \\
975(160) \\
91(67-104) \dagger \\
104(86-116)^{\star} \\
1.63(0.03) \\
88(74-98) \dagger \\
106(92-118)^{\star} \\
103(87-120) \\
270(9) \\
104(83-121)^{\star} \\
0.59(0 \cdot 04) \\
0.54(0.08)\end{array}$ & $\begin{array}{l}\text { NS } \\
\text { NS } \\
\text { NS } \\
\text { NS } \\
\text { NS } \\
\text { NS } \\
<0.05 \\
<0.001 \\
<0.01 \\
<0.001 \\
\text { NS } \\
\text { NS } \\
\text { NS } \\
\text { NS } \\
\text { NS } \\
<0.001 \\
<0.001 \\
<0.01 \\
\text { NS } \\
<0.01 \\
<0.01 \\
\text { NS } \\
\text { NS } \\
\text { NS } \\
\text { NS } \\
\text { NS } \\
\text { NS }\end{array}$ \\
\hline
\end{tabular}

NYHA, New York Heart Association class; \%, percentage of normal predicted; PARC, plasma active renin concentration. ${ }^{\star} p<0.01$, tp $<0.001$ compared with predicted normal (see text).

Values are mean (SEM) for absolute values and mean and range for percentage values.

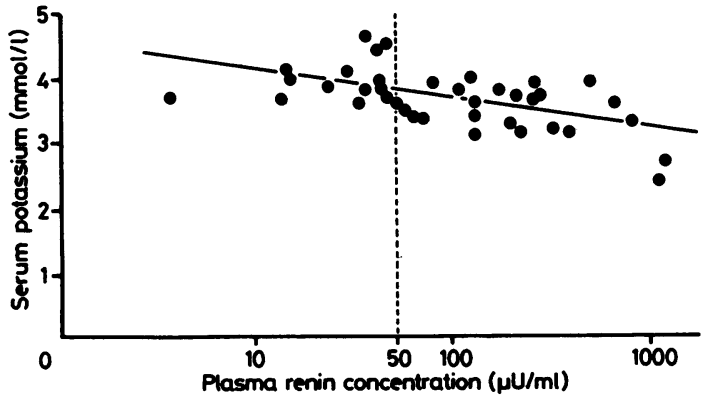

Fig 1 Relation between plasma active renin concentration (expressed on a log scale) and serum potassium in patients with heart failure. $(r=-0.57 ; p<0.001 ; n=40)$. Two points in the central cluster of the diagram completely overlap and only 38 points are actually visible.

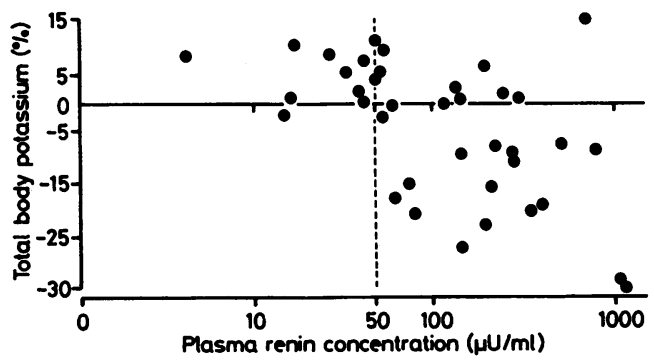

Fig 2 Relation between plasma active renin concentration (expressed on a log scale) and total body potassium (expressed as a percentage of prediced normal) in patients with heart failure. (Spearman's $R=-0.51 ; p<0.01$; $n=38$ ). 


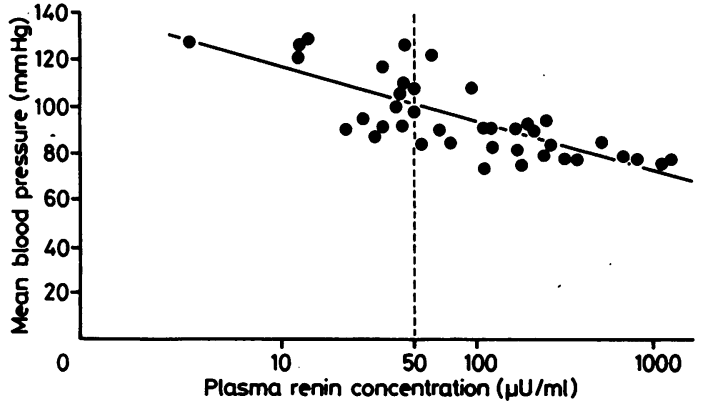

Fig 3 Relation between plasma active renin concentration (expressed on a log scale) and mean blood pressure in patients with heart failure. $(r=-0.76 ; p<0.001$; $n=40$ ).

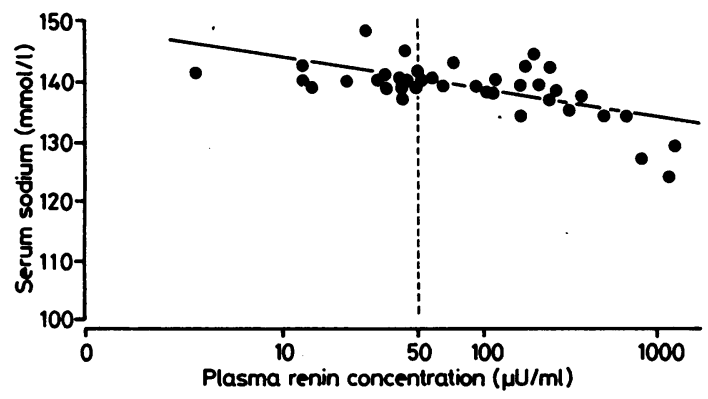

Fig 4 Relation between plasma active renin concentration (expressed on a log scale) and serum sodium in patients with heart failure. $(r=-0.67 ; p<0.001 ; n=40)$.

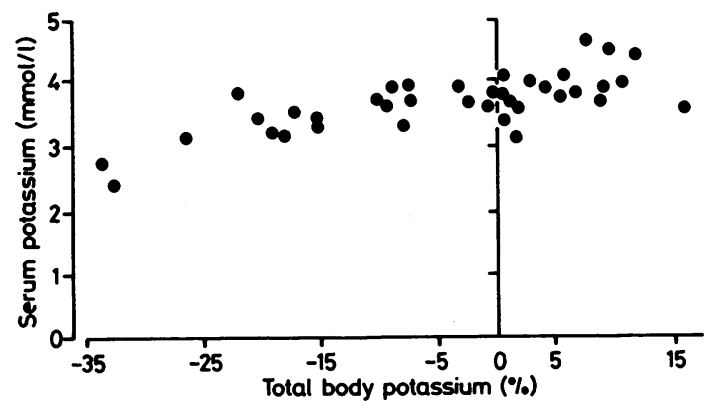

Fig 5 Relation between total body potassium (expressed as a percentage of predicted normal and serum potassium in patients with heart failure. (Spearman's $R=-0.72$; $p<0.001 ; n=38$ ).

centage of predicted normal) were significantly correlated $(r=0.72 ; p<0.001)$ (fig 5$)$ and this relation was maintained after correcting total body potassium for total body nitrogen $(r=0.75 ; p<0.001)$. The relation appeared linear over the measured range. A similar relation was not observed in the group with hypertension $(r=0 \cdot 1 ; N S$ and $r=0.3$;
NS). Serum sodium ( $r=0.1$ heart failure and $r=0.36$ hypertension) was not significantly related to total body sodium (percentage of predicted normal) but serum chloride was related to total body chlorine (percentage of predicted normal $(r=0.34$; $p<0.05$ heart failure and $r=0.59 ; p<0.01$ hypertension).

\section{Discussion}

\section{HYPERTENSION}

Hypertensive subjects have similar mean values for body element composition as normal subjects. ${ }^{1516}$ The present study confirmed that total body potassium in normal subjects and in those with untreated essential hypertension were similar. Older patients with hypertension ( $>49 \mathrm{yrs}$ ) do tend to have raised body sodium which positively correlated with their blood pressure while younger patients $(<36 \mathrm{yrs})$ have reduced body sodium and potassium which correlates inversely with their blood pressure. ${ }^{16} 17$ However, our hypertensive group, of an intermediate age, appeared to have a body composition that was similar to predicted normal for all elements measured. The limited range of values for serum and total body electrolytes in the hypertensive and normal groups compared with the heart failure group reduces the probability of finding significant relations. Chlorine, which is largely present in the extracellular space, ${ }^{24}$ did relate to serum concentrations of chloride. Potassium, a largely intracellular electrolyte, and sodium, much of which is present in bone $\mathrm{e}^{25}$ and so not freely exchangeable with the extracellular pool, were poorly related to serum concentrations.

The extracellular fluid volume in our hypertensive patients accorded well with reported figures, and in untreated hypertensive subjects seems to be similar to normal. ${ }^{33}$ The numbers with raised concentrations of plasma active renin in this study are too small to analyse the effects of this system on body composition.

\section{HEART FAILURE}

The present study clearly shows that total body potassium depletion does occur in patients with heart failure treated with digoxin and diuretics. Others have argued that potassium depletion in such patients is due to cachexia and a loss of protein (nitrogen) mass. ${ }^{114}$ Our study demonstrates that this is not the case, and in fact the tendency to higher body calcium and nitrogen suggests that adipose tissue may be preferentially lost in subjects with heart failure, with relative preservation of lean body mass. Indeed the percentage of body weight consisting of fat was lower in elderly subjects with heart failure 
than in age matched controls. ${ }^{34}$ James et al have argued that potassium depletion in cachectic patients is due to a loss of cellular nitrogen mass with preservation of collagen nitrogen mass, and that this accounts for the fall in potassium in relation to nitrogen in wasting diseases. ${ }^{14}$ They did not, however, specifically study patients with heart failure. Although Burkinshaw and Morgan noted a fall in potassium in relation to nitrogen in heart failure, they too were unable to distinguish between relative changes in collagen and cellular nitrogen because their control groups differed markedly from the study group. ${ }^{28}$ Our groups were well matched for height, weight, age, and sex and also had very similar total body nitrogen. If cell mass had been lost nitrogen values were likely to have fallen even if collagen nitrogen mass was preserved. Further support for a true depletion of potassium rather than a change in cellular mass comes from recent evidence that the total body potassium deficit can be corrected without a change in total body nitrogen by use of angiotensin converting enzyme inhibitors, which suppress angiotensin II mediated aldosterone secretion. ${ }^{1335}$ However, amiloride and spironolactone did not correct total body potassium deficits. ${ }^{3637}$

Others have reported only a poor non-linear relation between serum potassium and total body potassium. ${ }^{638}$ In our series, where diagnosis was tightly defined and treatment well documented and uniform, we found a good and apparently rectilinear relation between serum and total body potassium over the measured range. Multiple blood sampling may improve this relation. Diurnal variation in potassium concentration ${ }^{39}$ is likely to be exaggerated by diuretic treatment. Total body potassium would not be expected to respond in such a rapid manner. Unfortunately multiple samples were not available in hypertensive patients and this may be one reason for the poorer relation observed in those cases.

Diuretic treatment may not be the only explanation for potassium depletion; when patients with high and normal or low plasma active renin concentration were compared, only the former were significantly potassium depleted, though the diuretic dose was very similar in the two groups. After appropriate corrections for nitrogen, however, a small reduction in potassium was detected in the subgroup with low plasma concentrations of active renin. Potassium supplements were also greater in the high renin/low potassium subgroup; this is compatible with the view that potassium supplements are ineffective in correcting diuretic-induced potassium depletion. ${ }^{240}$ Stimulation of the reninangiotensin-aldosterone axis will increase renal potassium excretion, but potassium not only stimu- lates the secretion of aldosterone but also suppresses renin secretion. ${ }^{4142} \mathrm{~A}$ fall in potassium could then allow a further rise in renin, leading to this inverse relation.

Concentrations of serum bicarbonate were higher in patients with heart failure, as might be expected in the presence of hypokalaemia, but bicarbonate concentrations were similar in normal and high $\vec{\circ}$ renin subgroups despite significant differences in serum and total body potassium. A long term increase in serum bicarbonate and alkalosis may be less important in the regulation of intra/extracellular potassium ratio in treated heart failure, though it may have a short term regulatory role.

Another feature of interest is the lack of any clear difference in New York Heart Association class, total body sodium, or total body chlorine between subgroups with high or low concentrations of plasma active renin. Where there were statistically insignificant differences they were accounted for by changes in the concentration of the respective electrolytes in the extracellular space. Extracellular fluid volume, even when corrected for weight, was similar in the two groups, suggesting that volume changes are less important in determining renin-angiotensin activity in treated heart failure; however, intravascular volume, which may be important, was not measured. Apart from potassium the only clear differences between high and low renin subgroups were serum concentrations of sodium and mean blood pressure. In heart failure it is likely that these three influences are of prime importance in setting the level of renin-aldosterone-angiotensin activity. ${ }^{4344}$

Although the heart failure group as a whole had worse renal function, with relatively greater urea than creatinine retention, than the hypertensive group, there were no differences between patients with heart failure in high and low renin subgroups. This suggests that angiotensin II appears not to affect renal function adversely and may well have sustained glomerular filtration and urea excretion in the face of a falling renal blood flow and renal perfusion pressure in our patients. ${ }^{1143}$ Possibly renal function would have been more abnormal in patients ? with more extreme increases in angiotensin II. ${ }^{43}$

Extracellular fluid volume remained increased in these oedema free patients with heart failure; it is not $\sigma_{2}$ clear whether further diuretic treatment would have 0 corrected this. Surprisingly, total body oxygen, an index of total body water ${ }^{23}$ was reduced in patients $\stackrel{\oplus}{?}$ with heart failure, suggesting intracellular dehy- 0 dration. Thus although potassium depletion occurs in heart failure the actual concentration of intra- $\stackrel{\mathbb{D}}{\Omega}$ cellular potassium may be less abnormal than $\underset{\mathbb{D}}{\mathbb{D}}$ expected. Total body sodium was $300 \mathrm{~mol}$ greater in 
$300 \mathrm{~mol}$ greater in patients with heart failure, and less than half of this difference can be explained by the increase in extracellular fluid volume. The rest could be explained either by an increase in sodium in bone or an increase in intracellular concentrations, because sodium may replace intracellular potassium losses. The alteration in the calcium/phosphorus ratio also suggests a change in bone metabolism, which is not dependent upon the stimulation of renin. Bone calcium was increased by thiazide diuretics, ${ }^{45}$ which reduce urinary calcium excretion $^{46}$; however, most of our patients were only on frusemide, which increases urinary calcium excretion. Alternatively the increase in the concentration of bicarbonate may have altered the relation between calcium and phosphorus.

The one year survival of subjects with New York Heart Association grade III heart failure is around $60 \%$ and most deaths are sudden-this accords with the frequency of ventricular arrhythmias. ${ }^{1047}$ Potassium depletion may provoke arrhythmias ${ }^{48}$ and this effect may be exaggerated by digoxin. ${ }^{49}$ Body potassium is largely concentrated in skeletal muscle, ${ }^{50}$ which probably acts as a buffer for serum potassium. Depletion of intracellular potassium may lead to much greater short term falls in serum potassium caused by diuretics, changes in $\mathrm{pH}$, or adrenergic activity. ${ }^{51}$ Additionally, myocardial potassium concentrations appear to be protected and do not fall when skeletal muscle and serum potassium fall. ${ }^{52}$ This could lead to unfavourable changes in transmembrane potential and intramyocardial conduction, further potentiating arrhythmias. If this is so correction of potassium deficits may improve prognosis.

\section{References}

1 Morgan DB, Burkinshaw L, Davidson C. Potassium depletion in heart failure and its relation to long-term treatment with diuretics: a review of the literature. Postgrad Med J 1978;54:72-9.

2 Davidson C, Burkinshaw L, McClachlan MSF, Morgan DB. Effect of long-term diuretic treatment on body potassium in heart disease. Lancet 1976;ii:1044-52.

3 Lawson DH, Boddy K, Gray JMB, Mahaffy ME, Mills E. Potassium supplements in patients receiving longterm diuretics for oedema. $Q J$ Med 1976;45:469-78.

4 Lye $M$, Winston $B$. Whole body potassium and total exchangeable potassium in elderly patients with heart failure. Br Heart $J$ 1979;42:568-72.

5 Lye M. Body potassium content and capacity of elderly individuals with and without cardiac failure. Cardiovasc Res 1982;16:22-5.

6 Flear CTG, Cooke WT, Quinton A. Serum potassium levels as an index of body content. Lancet 1957; i:458-9.

7 Surveyor I, Hughes D. Discrepancies between wholebody potassium content and exchangeable potassium. J Lab Clin Med 1968;71 (part 3):464-71.

8 Boddy K, King PC, Hume R, Weyers E. The relation of total body potassium to height, weight and age in normal adults. J Clin Pathol 1972;25:512-7.

9 Franciosa JA, Wilen M, Ziesche S, Cohn JN. Survival in men with severe chronic left ventricular failure due to either coronary heart disease or idiopathic dilated cardiomyopathy. Am J Cardiol 1983;51: 831-6.

10 Unverferth DV, Magorien RD, Moeschberger ML, Baker PB, Fetters JK, Leier CV. Factors influencing the one-year mortality of dilated cardiomyopathy. Am J Cardiol 1984;54:147-52.

11 Cleland JGF, Dargie HJ, Hodsman GP, et al. Captopril in heart failure: a double blind controlled study. Br Heart $J$ 1984;52:530-5.

12 Cleland JGF, Dargie HJ, Ball SG, et al. Effects of enalapril in heart failure: a double blind study of effects on exercise performance, renal function, hormones, and metabolic state. $\mathrm{Br}$ Heart $J$ 1985;54:305-12.

13 Preston T, Reeds PJ, East BW, Holmes PH. A comparison of body protein in rats by in vivo neutron activation and carcass analysis. Clin Sci 1985;68: 349-55.

14 James HM, Dabek JT, Chettle DR, et al. Whole body cellular and collagen nitrogen in healthy and wasted man. Clin Sci 1985;67:73-82.

15 Williams ED, Boddy K, Brown JJ, et al. Whole body elemental composition in patients with essential hypertension. Eur J Clin Invest 1982;12:321-5.

16 Lever AF, Beretta-Piccoli C, Brown JJ, et al.Sodium and potassium in essential hypertension. $\mathrm{Br} M e d \mathrm{~J}$ 1981;283:463-8.

17 Beretta-Piccoli C, Davies DL, Boddy K, et al. Relation of arterial pressure with body sodium, body potassium and plasma potassium in essential hypertension. Clin Sci 1982;63:257-70.

18 Boddy K, King PC, Tothill P, Strong JA. Measurement of total body potassium with a shadow shield whole-body counter: calibration and errors. Phys Med Biol 1971;16:275-82.

19 Williams ED, Boddy K, Harvey I, Haywood JK. Calibration and evaluation of a system for total body in vivo activation analysis using $14 \mathrm{MeV}$ neutrons. Phys Med Biol 1978;23:405-15.

20 Boddy K, Williams ED, Haywood JK, Harvey I, Harris IA. Scanning in vivo activation analysis: methods and medical applications. In: Nuclear activation techniques in the life sciences 1978. Vienna: International Atomic Energy Agency, 1979:775-86.

21 Haywood JK, Harris I, Boddy K, Williams ED. A twoway scanning method for total body in vivo neutron activation analysis. Phys Med Biol 1978;23:865-75.

22 Boddy K, Elliot A, Robertson I, Mahaffy ME, Holloway I. A high sensitivity dual-detector shadowfield whole-body counter with and "invariant" response for total body in vivo neutron activation analysis. Phys Med Biol 1975;20:296-304. 
23 Williams ED, Boddy K. Measurement of whole-body oxygen in living humans by neutron activation analysis. Int J Appl Rad Isot 1978;29:281-3.

24 Ellis KJ, Vaswani A, Zanzi I, Cohn SH. Total body sodium and chlorine in normal adults. Metabolism 1976;25:645-54.

25 Ellis KJ, Cohn SH. Correlation between skeletal calcium mass and muscle mass in man. J Appl Physiol 1975;38:455-60.

26 Skrabal F, Arnot RN, Joplin GF. Equations for the prediction of normal values for exchangeable sodium, exchangeable potassium, extracellular fluid volume, and total body water. $\mathrm{Br} \mathrm{Med} J$ 1973;ii:37-8.

27 Yasumura S, Cohn SH, Ellis KJ. Measurement of extracellular space by total body neutron activation. Am J Physiol 1983;244:R36-40.

28 Burkinshaw L, Morgan DB. Mass and composition of the fat-free tissues of patients with weight-loss. Clin Sci 1985;68:455-62.

29 Ball SG, Tree M, Morton JJ, Inglis GC, Fraser R. Circulating dopamine: its effect on the plasma concentrations of catecholamines, renin angiotensin, aldosterone and vasopressin in the conscious dog. Clin Sci 1981;61:417-22.

30 Millar JA, Leckie BJ, Semple PF, Morton JJ, Sonkodi $S$, Robertson JIS. Active and inactive renin in human plasma: renal arteriovenous differences and relationships with angiotensin and renin substrates. Circ Res 1978;43(suppl 1):120-7.

31 Fraser R, Guest S, Young J. Comparison of double isotope derivative and radio-immunological estimation of plasma aldosterone concentration. Clin Sci Mol Med 1973;45:411-5.

32 Atkinson AB, Morton JJ, Brown JJ, et al. Captopril in clinical hypertension. Changes in components of the renin-angiotensin system and in body composition in relation to fall in blood pressure with a note on measurement of angiotensin II during converting enzyme inhibition. Br Heart $J$ 1980;44:290-6.

33 Schalekamp MA, Lebel M, Beevers DG, Fraser P, Kolsters G, Birkenhager WH. Body fluid volume in low-renin hypertension. Lancet 1974;ii:310-1.

34 Lye $\mathrm{M}$. Body potassium content and capacity of elderly individuals with and without cardiac failure. Cardiovasc Res 1982;16:22-5.

35 Cleland JGF, Dargie HJ, East BW, et al. Total body and serum electrolyte composition in heart failure: the effects of captopril. Eur Heart $J$ 1985;6:681-8.

36 Davidson C, Gillebrad IM. Use of amiloride as a potassium conserving agent in severe cardiac disease. $\mathrm{Br}$ Heart $J$ 1973;35:456-61.

37 Davidson C, Burkinshaw L, Morgan DB. The effect of potassium supplements, spironolactone or amiloride on the potassium status of patients with heart failure. Postgrad Med J 1978;54:405-9.

38 Moore FD, Edelman IS, Olney JM, James AH, Brooks L, Wilson GM. Body sodium and potassium: 111. Inter-related trends in alimentary, renal and cardiovascular disease, lack of correlation between body stores and plasma concentration. Metabolism 1954;3:330-50.

39 Ede MCM, Brennan MF, Ball MR. Circadian variation of intercompartmental potassium fluxes in man. $J$ Appl Physiol 1975;38:163-70.

40 MacLennan WJ, Lye MDW, May T. The effect of potassium supplements on total body potassium levels in the elderly. Age Ageing 1977;6:46-50.

41 Sealey JE, Kirsham JD, Laragh JH. Natriuretic activity in plasma and urine of salt-loaded man and sheep. $J$ Clin Invest 1969;48:2210-7.

42 Oparil S, Haber E. The renin-angiotensin system. $N$ Engl J Med 1974;291:389-94.

43 Brown JJ, Davies JL, Hohnson VW, Lever AF. Robertson JIS. Renin relationships in congestive cardiac failure, treated and untreated. Am Heart $J$ 1970;80:329-42.

44 Levine TB, Franciosa JA, Vrobel T, Cohn JN. Hyponatraemia as a marker for high renin heart failure. $\mathrm{Br}$ Heart $J$ 1982;47:161-6.

45 Wasnich RD, Benfante RJ, Yano K, Heilburn L, Vogel JM. Thiazide effect on the mineral content of bone. N Engl J Med 1983;309:344-7.

46 Brickman AS, Massry SG, Coburn JW. Changes in serum and urinary calcium during treatment with hydrochlorothiazide: studies on mechanisms. J Clin Invest 1972;51:945-53.

47 Meinertz T, Hofman T, Kasper W, et al. Significance of ventricular arrhythmias in idiopathic dilated cardiomyopathy. Am J Cardiol 1984;53:902-7.

48 Holland OB, Nixon JD, Kuhnert L. Diuretic induced ventricular ectopic activity. $\mathrm{Am} J \mathrm{Med}$ 1981;70:762-8.

49 Steiness E, Olesen KH. Cardiac arrhythmias induced by hypokalaemia and potassium loss during maintenance digoxin therapy. Br Heart $J$ 1976;38:167-72.

50 Knochel JP. Rhabdomyolysis and effects of potassium deficiency on muscle structure and function. Cardiovasc Med 1978;3:247-61.

51 Struthers AD, Reid JL. The role of adrenal medullary catecholamines in potassium homeostasis. Clin $\mathrm{Sci}$ 1984;66:377-82.

52 Knochel JP, Foley FD, Lipscomb K. High resting cardiac output with exercise-induced pulmonary oedema in the conscious, potassium-deficient dog. Mineral Electrolyte Metabolism 1978;1:336-44. 